\title{
Characterization of photoautotrophic microbial communities in the coastal water of Lake Baikal
}

LIMNOLOGY FRESHWATER

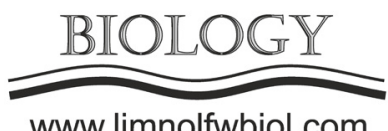

\author{
Belykh O.I. ${ }^{1}$, Tikhonova I.V. ${ }^{1 *}$, Krasnopeev A.Yu. ${ }^{1}$, Galachyants A.D. ${ }^{1}$, \\ Sukhanova E.V. ${ }^{1}$, Suslova M.Yu. ${ }^{1}$, Gorshkova A.S. ${ }^{1}$, Gevorgyan G. ${ }^{2}$, Potapov S.A. ${ }^{1}$ \\ ${ }^{1}$ Limnological Institute, Siberian Branch of the Russian Academy of Sciences, Ulan-Batorskaya Str., 3, Irkutsk, 664033, Russia \\ ${ }^{2}$ Scientific Center of Zoology and Hydroecology, National Academy of Sciences of Republic of Armenia, Paruyr Sevak str. 7, 0014, \\ Yerevan, Armenia
}

\begin{abstract}
In this study, we determined the concentration of chlorophyll $a$ in biofilms formed on rocky substrates, in the surface water microlayer, water column, and near-bottom water layer of the coastal zone of Lake Baikal. High throughput sequencing of 16S rRNA and rbcL gene libraries revealed high genetic and taxonomic diversity of photoautotrophic microbial communities in the studied ecotopes of the lake. The UPGMA analysis indicated that the composition of photoautotrophic communities largely depends on both the geographical location and ecotope. Using electron microscopy, we described the structure and composition of biofilms.
\end{abstract}

Keywords: cyanobacteria, algae, 16S rRNA, RuBisCO, high throughput sequencing, Lake Baikal

\section{Introduction}

Photoautotrophic oxygenated microorganisms, mainly cyanobacteria and algae, convert carbon dioxide and water into an organic matter during photosynthesis using visible light as an energy source and, thus, release oxygen. Thanks to the activity of photoautotrophs, the existence of heterotrophic organisms that consume organic substances and aerobic organisms that require oxygen becomes possible. Moreover, cyanobacteria fix molecular oxygen and are highly resistant to the adverse factors caused by morphological and physiological properties. These unique properties of photoautotrophic microorganisms contribute to their ubiquitous distribution: they are the first to occupy various aquatic ecotopes, often forming benthic and plankton blooms as well as biofouling of different substrates.

We aimed to study the composition and structure of photoautotrophic microbial communities in the coastal zone of Lake Baikal using microscopy methods and high throughput sequencing of amplicons of $16 \mathrm{~S}$ rRNA and RuBisCO (ribulose bisphosphate carboxylase/ oxygenase) genes.

\section{Material and methods}

Samples of biofilms from rocky substrates, surface water microlayer, water column, and near-bottom water layer were taken in August 2019 in the coastal zone opposite the settlements of Bolshiye Koty and
Bolshoye Goloustnoye. Chlorophyll a concentration was measured by spectrophotometric method (Jeffrey and Humphry, 1975). Genomic DNA was extracted using phenol chloroform solution. DNA amplification was performed using primers targeting V3 and V4 regions of the 16S rRNA gene (Martemyanov et al., 2016). The large subunit of RuBisCO (rbcL) gene fragments was amplified with previously published rbcL primers (Wawrik et al., 2002). Sequencing of 16S rRNA and rbcL gene libraries was conducted on a MiSeq genome sequencer (Illumina). Sequence fragments of 16S rRNA and $\mathrm{rbcL}$ gene were filtered, trimmed and merged using DADA2 $\mathrm{R}$ language package following standard operating procedure (SOP) (Callahan et al., 2016). Taxonomic assignment of 16S RNA gene fragments was performed with SILVA SSU database v. 132 (Quast et al., 2013). Sequence fragments of rbcL gene were annotated with using BLAST toolkit search. AlgaeBase was used for systematic and ecology information about the algae (Guiry and Guiry, 2020).

Scanning electron microscopy (SEM) was used for the detailed analysis of the biofilm structures (Sorokovikova et al., 2013).

\section{Results and discussion}

The results of determining the chlorophyll a concentrations as an indicator of the productivity of photoautotrophs revealed the maximum values in the upper and near-bottom water layers (2.78-5.88 $\mu \mathrm{g} / \mathrm{l})$.

*Corresponding author.

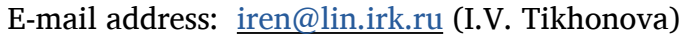

(C) Author(s) 2020. This work is distributed under the Creative Commons Attribution 4.0 License. 
The minimum concentrations were recorded in the water column (1.34-4.3 $\mu \mathrm{g} / \mathrm{l})$. However, they were higher than those in the pelagic zone of the lake at that time. The chlorophyll a concentrations in biofilms averaged $342.7 \mu \mathrm{g} / \mathrm{l}$ near Bolshoye Goloystnoye and 445.7 near Bolshiye Koty. On the contrary, plankton showed the highest chlorophyll a concentration near Bolshoye Goloustnoye.

We obtained 169497 16S rRNA gene sequences with an average length of $418 \mathrm{bp}$. The phyla Cyanobacteria, Actinobacteria, Proteobacteria, Bacteroidetes, Verrucomicrobia, Firmicutes, Fusobacteria, and Acidobacteria dominated bacterial communities. The proportion of Cyanobacteria in the total number of sequences averaged $17.5 \%$; the number of OTUs was 37.

Picoplankton species of the cluster Synechococcus/ Cyanobium (14 OTUs) and Dolichospermum lemmermannii (3 OTUs) mainly represented cyanobacteria in neuston and plankton. Benthic and periphyton species, Synechococcus sp., Calothrix sp., Tychonema sp., and Pseudanabaena sp., were very few in the water. $D$. lemmermannii was the most numerous near Bolshiye Koty. Previously, we showed that this mass species in Baikal phytoplankton is a producer of paralytic mollusc toxins (Belykh et al., 2015). Among the three aquatic microbiocenoses, water column had the greatest biodiversity (16 OTUs).

In fouling of rocky substrates, we identified 20 OTUs of cyanobacteria belonging to the orders Nostocales, Oscillatoriales, Chroococcales, and Synechococcales. The main species were Tychonema sp., Phormidium sp., Symplocastrum sp., and Pseudanabaena sp. Near Bolshiye Koty, we detected Chamaesiphon sp., Leptolyngbya sp., Synechococcus sp., and Calothrix sp. In biofilms, chroococcal cyanobacteria, which are closely related to the clones that we previously detected in the fouling of sick sponges (Sorokovikova et al., 2020), as well as picoplankton cyanobacteria, were abundant

Based on the analysis of the chloroplast $16 \mathrm{~S}$ rRNA gene, benthic diatoms and planktonic green algae prevailed in biofilms. In plankton, we detected Nannochloropsis limnetica (Eustigmatophyceae), Nannochloris bacillaris и Choricystis sp. (Chlorophyta), Chrysochromulina parva (Haptophyta), Spirogyra sp. (Charophyta), Teleaulax sp. (Cryptophyta), Synura sp. (Ochrophyta, Synurophyceae), Dictyochophyceae, and Chlorokybus sp. (Charophyta).

Analysis of fragments of the gene coding ribulose bisphosphate carboxylase/oxygenase, the main enzyme of photosynthesis ( $\mathrm{rbcL}$ ), revealed the high algal diversity in the studied ecotopes. We obtained 34531 rbcL gene sequences with an average length of $554 \mathrm{bp}$. The number of OTUs in the samples was 141. Among them, 70 OTUs were diatoms, which were the most diverse in benthic samples (55 OTUs). In biofilms, members of the genera Ellerbeckia, Amphora, Cocconeis, Nitzschia, Cymbella, Diploneis, Didymosphenia, Navicula, and Achnanthes dominated. In plankton and neuston, haptophyte Ch. parva and Chrysophyta (Ochromonas spp., Chrysosphaerella sp., Mallomonas spp., and Uroglenopsis sp.) prevailed. Additionally, we also often detected Pedinella spp. (Dictyochophyceae), $N$. limnetica, Nitzschia draveillensis, Nitzschia sp., Ulnaria sp. (previously Synedra acus), Lindavia spp., (previously Cyclotella baicalensis and C. minuta), Fragilaria sp. (Bacillariophyta), and Teleaulax (Cryptophyta).

According to the UPGMA analysis, algae and cyanobacteria from biofilms sampled near Bolshiye Koty and Bolshoye Goloustnoye form a common "benthic" clade, and planktonic and neustonic representatives form a common "aquatic" clade. Benthic communities tend to cluster depending on the geographical location, like planktonic and neustonic cyanobacteria from the Bolshiye Koty area (Fig.). Neustonic and planktonic algae do not manifest this.

The study of biofilms using the scanning electron microscopy indicated that diatoms and cyanobacteria were the structural basis of biofilms. In some cases, biofilms were mainly formed by diatoms of the genus Cocconeis, and in other cases - by filamentous cyanobacteria of the orders Nostocales and Oscillatoriales.

\section{Conclusions}

Cyanobacteria and algae in the coastal zone of Lake Baikal have high productivity from the bottom to the surface, including fouling of rocky substrates. High genetic and taxonomic diversity characterises photoautotrophic communities from various ecotopes of the coastal zone. Geographic location and ecological niche significantly affect the composition of communities. The main feature of the microbial communities from the coastal zone of Lake Baikal in the summer is a predominance of cyanobacteria. In plankton, picocyanobacteria and nitrogen-fixing potentially toxic representatives of Nostocales are numerous. In benthos, species of the order Oscillatoriales dominate. Diatoms, the most diverse and numerous among photoautotrophic eukaryotes, mostly inhabit rocky substrates. Like cyanobacteria, diatoms form complex and structurally organised biofilms. The sufficient supply of nutrients and trace elements from the sub-bottom water and substrates contributes to their successful development in the coastal zone of the lake.

\section{Acknowledgements}

This work was carried out within the State Task, project No. 0345-2019-0003 (Microbial and viral communities in biofilms...; AAAA-A16-116122110061-6) and the Science Committee of MES Republic Armenia and the Russian Foundation for Basic Research within the frame of the joint research project under grant Nos. 18RF-075 and 18-54-05005 Arm_a.

\section{References}

Belykh O.I., Gladkikh A.S., Sorokovikova E.G. et al. 2015. Saxitoxin-producing cyanobacteria in Lake Baikal. 
Cluster Dendrogram

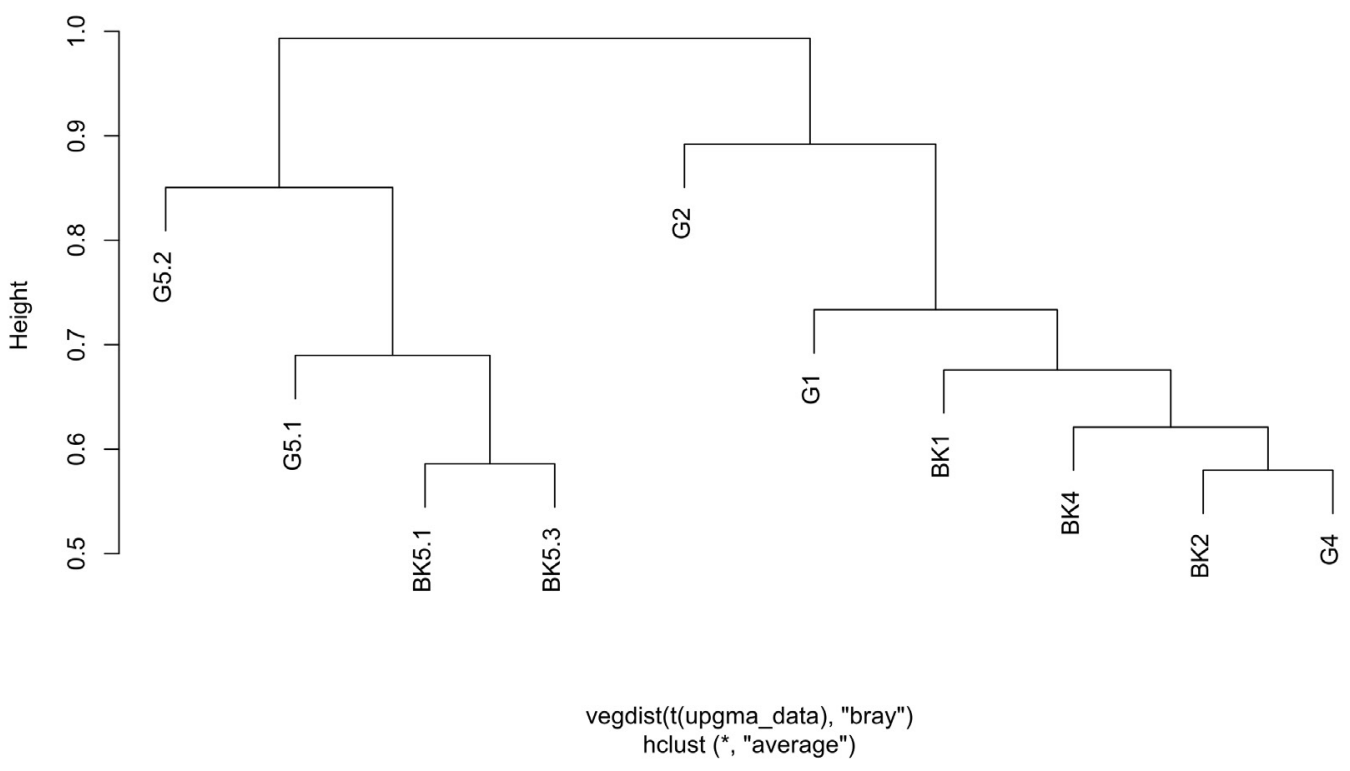

Fig. Dendrogram of the rbcL communities from water, surface microlayer and epilithic biofilms constructed using hierarchical cluster analysis (hclust) by the UPGMA method. G - Bolshoye Goloustnoye, BK - Bolshiye Koty; G1, BK1 - surface water microlayer, G2, BK2 - water column, G4, BK4 - near-bottom water, and G5.1, G5.2, BK5.1, BK5.3 - epilithic biofilms.

Contemporary Problems of Ecology 8: 186-192. DOI: 10.1134/S199542551502002X

Callahan B., McMurdie P., Rosen M. et al. 2016. DADA2: High-resolution sample inference from Illumina amplicon data. Nature Methods 13: 581-583. DOI: 10.1038/nmeth.3869

Guiry M.D., Guiry G.M. 2020. AlgaeBase. World-wide electronic publication, National University of Ireland, Galway. https://www.algaebase.org; searched on 08 June 2020.

Jeffrey S. W., Humphrey G. F. 1975. New spectrophotometric equations for determining chlorophylls $a$, $b, c 1$ and $c 2$ in higher plants, algae and natural phytoplankton. Biochemie und Physiologie der Pflanzen 167: 191-194. DOI: 10.1016/S0015-3796(17)30778-3

Martemyanov V.V., Belousova I.A., Pavlushin S.V. et al. 2016. Phenological asynchrony between host plant and gypsy moth reduces insect gut microbiota and susceptibility to Bacillus thuringiensis. Ecology and Evolution 6: 7298-7310. DOI: 10.1002 /ece 3.2460

Quast C., Pruesse C., Yilmaz P. et al. 2013. The SILVA ribosomal RNA gene database project: improved data processing and web-based tools. Nucleic Acids Research 41: 590-596. DOI: 10.1093/nar/gks1219

$\mathrm{R}$ : a language and environment for statistical computing. 2014. Foundation for Statistical Computing, Vienna, Austria. http://www.R-project.org/

Sorokovikova E.G., Belykh O.I., A.S. Gladkikh et al. 2013. Diversity of cyanobacterial species and phylotypes in biofilms from the littoral zone of Lake Baikal. Journal of Microbiology 51: 757-765. DOI: 10.1007/s12275-013-3240-4

Wawrik B., Paul J., Tabita F. 2002. Real-time PCR quantification of rbcL (ribulose-1, 5-bisphosphate carboxylase/oxygenase) mRNA in Diatoms and pelagophytes. Applied and Environmental Microbiology 68: 3771-3779. DOI: 10.1128/aem.68.8.3771-3779.2002

Sorokovikova E., Belykh O., Krasnopeev A. et al. 2020. First data on cyanobacterial biodiversity in benthic biofilms during mass mortality of endemic sponges in Lake Baikal. Journal of Great Lakes Research 46: 75-84. DOI: 10.1016/j. jglr.2019.10.017 